\title{
Absolute growth and biomass of Gracilaria sp. That cultivated under different depths
}

\author{
Nurlaila Ervina Herliany*, Zamdial, Rahma Febriyanti \\ Departement of Marine Science, University of Bengkulu, Kandang Limun Bengkulu \\ ${ }^{*}$ Corresponding author email: vivien.unib@gmail.com
}

Submitted: 13 Juli 2017 / Revised: 22 Desember 2017 / Accepted: 22 Desember 2017

http://dx.doi.org/10.21107/jk.v10i2.2986

\begin{abstract}
There is significant increase of seaweeds demand over the years that affect the development of seaweeds farming in Indonesia. Gracilaria sp. is one of the species that cultivated in Indonesia. There are some factors that affect the successful of seaweeds cultivation, one of them is cultivation depth. The research was carried out to study the effect of different depth on absolute growth and biomass of Gracilaria sp. It was cultivated under three different depths $(30,45$ and $60 \mathrm{~cm})$. Absolute growth and biomass were influenced by cultivation depth. The best treatment was cultivation at $30 \mathrm{~cm}$ of depth. Water quality measurements shows that research location is suitable for the growth of seaweeds.
\end{abstract}

Keywords: Absolute growth, Biomass, Cultivation depths, Gracilaria sp.

\section{INTRODUCTION}

Seaweeds, known as macroalgae, are among the most important primary producers and act as ecological engineers on rocky coasts of the world's oceans. They are primary producers, shelter, nurserygrounds and food sources for marine organisms. Seaweeds are not only of high ecological, but also of great economic importance (Domettila et al., 2013). Seaweeds have been using as a part of human diet in China, Japan, Thailand and South Korea for many years.

Depends on species, some seaweeds are generally suitable for making cool, gelatinous dishes or concoctions. In general, seaweeds are considered as low calorie food item, but rich in vitamin, mineral and dietary fibre. Seaweeds are also utilized as animal feed ingredient, row material for fertilizer and as well as various industrial applications (Siddique et al., 2013).

The wider use of seaweed and its derivatives resulted in increased demand in the world. The increase in demand has an impact on the development of seaweed cultivation in several countries in the world, including Indonesia. Worldwide, macroalgal production increases $5.7 \%$ every year and more than 18 million tons of macroalgae were produced from global capture and aquaculture in 2011. In 2011,
$96 \%$ of the global total production of macroalgae came from aquaculture, with Asian countries dominating seaweed culture production ( $99.05 \%$ by quantity and $99.36 \%$ by value) (FAO, 2014 in Rebours et al., 2014).

Gracilaria sp. is one type of seaweed which is widely cultivated in Indonesia. It is based on its ability to produce high biomass, wide tolerance of environmental factors such as temperature and salinity, and the high economic value of its derivative products (Marinho-Soriano et al., 2009). This seaweed can also be found almost throughout the waters of Indonesia making it easier to get the seeds in the cultivation.

The optimal seaweed cultivation result can not be separated from several factors, one of them is the depth factor of cultivation. Previous studies indicate that seaweeds show different ecophysiological characteristics in response to depth changes during growth (Oliveira et al., 2012). The depth of cultivation affects the absorption of light by seaweeds so it is related to the process of photosynthesis that produces food for its growth (Aslan, 1998). To obtain optimal depth for the cultivation of Gracilaria $\mathrm{sp}$., it is necessary to do research to know the effect of depth to the absolute growth and the biomass. The purpose of this study was to obtain the optimal cultivation depth for the absolute growth and biomass of Gracilaria sp. 


\section{MATERIALS AND METHOD}

Seaweed seeds of Gracilaria sp. obtained from the waters of Linau, Kabupaten Kaur, Bengkulu Province. Seaweed cultivation is conducted in the waters of Teluk Pulau Baai, Bengkulu Province. The cultivation is done by the method of cutting thallus. Seaweed seeds are selected from a good thallus, with charactersitics such as the young thallus (the thallus at the end), the colour is bright red and not pale, and not slimy. The planting medium used is a bamboo raft, with a length of 3.3 meters and a width of 1.2 meters. The weight of the seaweed seeds used is 100 grams per clump. Seedlings are planted at three different depths, ie 30,45 and $60 \mathrm{~cm}$ from the water surface with the spacing between the clump is $30 \mathrm{~cm}$. Each depth of cultivation consists of 3 ropes, each rope is planted with 10 clumps of seaweed seeds, so the total seaweed planted is 30 clumps per depth (Fig. 1).

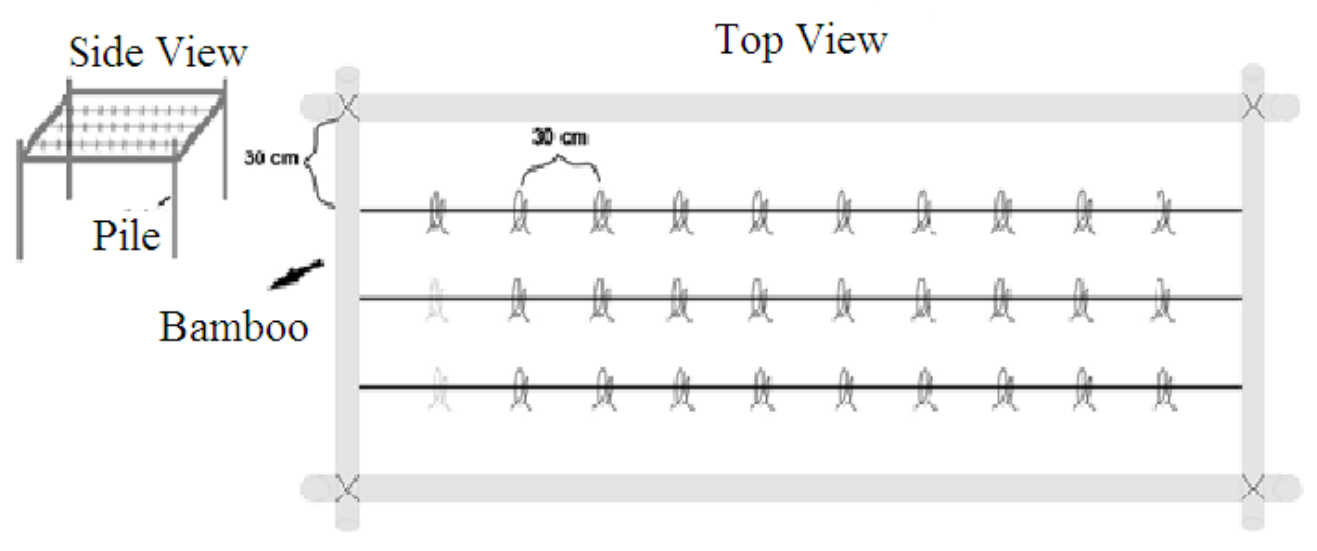

Figure 1. Sketch of Gracilaria sp. culture media

Every 5 days during 45 days of cultivation, seaweed is observed for absolute growth and biomass. Absolute growth is calculated using the Effendie (1997) formula:

$$
\Delta W=W t-W o
$$

Where $\Delta \mathrm{W}$ is absolute growth in grams, $\mathrm{Wt}$ is the wet weight of t-day $(\mathrm{g})$ and Wo is the initial wet weight $(\mathrm{g})$. Seaweed biomass is calculated using Gannesan et al. (2009):

$$
Y=\frac{W t-W o}{A}
$$

Multiple Range Test (DMRT).

\section{RESULTS AND DISCUSSION}

\section{Absolute Growth and Biomass}

Based on the research results, the absolute growth of Gracilaria sp. ranging from 10,000 to $49,583 \mathrm{~g}$ and the biomass of Gracilaria sp. ranging from 2,525 - $12,521 \mathrm{~g} / \mathrm{m}^{2}$. Absolute growth and seaweed biomass of Gracilaria sp. increased in the second observation and began to decrease in the third observation until the end of cultivation (Figure 2). The longer the cultivation period, the weight of seaweed is increasing. In accordance with the opinion of
Where $Y$ is biomass $\left(\mathrm{g} / \mathrm{m}^{2}\right)$, Wt is the wet weight of t-day $(\mathrm{g})$, Wo is the initial wet weight (g) and $A$ is the area of cultivation $\left(\mathrm{m}^{2}\right)$. Water quality includes temperature, salinity, $\mathrm{pH}$, transparency and current velocity, measured at the beginning, middle and end of cultivation. Absolute growth and biomass data were analyzed using Completely Randomized Design (CDR) at 95\% confidence level. The treatment was used is 3 different depths (30, 45 and $60 \mathrm{~cm}$ ) and each treatment was repeated 9 times. If the anova results show differences, then proceed with Duncan

Abdan et al. (2013), it has impact on the increasing competition for nutrients and sunlight for the process of photosynthesis so absolute growth and biomass decreases. Wenno et al. (2015) also stated that plant density affects the speed of nutrient absorption by seaweed so that at the beginning of cultivation, growth and biomass is higher and decreases with longer cultivation. In addition, an individual's growth will be optimal when the age of the individual is younger. According to Sahabuddin \&Tangko (2008) young cells and thallus tissue provide optimal growth. This 
opinion is in line with the opinion of Widyanto \& Suliso (1977) which states that the rate of mineral absorption of plants is greater at the

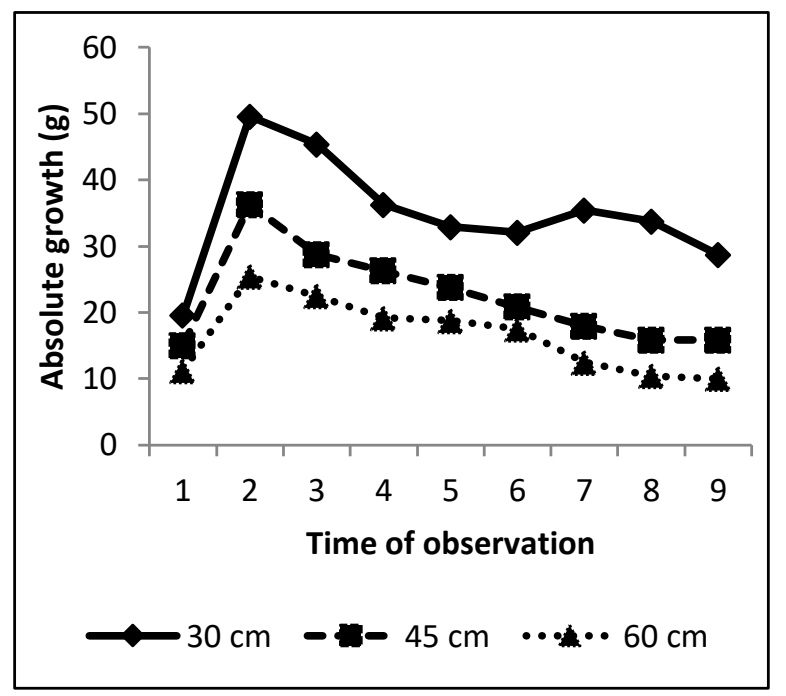

a) Absolute growth of Gracilaria sp. beginning of growth than when the plants were old.

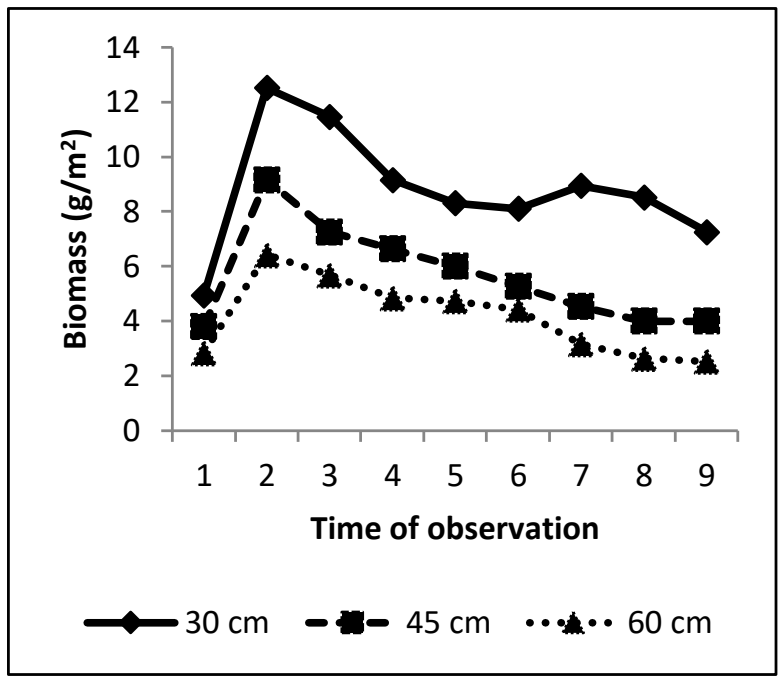

b) Biomass of Gracilaria sp.

Figure 2. Absolute growth and biomass of Gracilaria sp. under different depth during cultivation

The rate of seaweed growth is also influenced by the rate of photosynthesis. Lakitan (2011) states that the rate of photosynthesis is influenced by the age or developmental stadia of the photosynthetic organ itself. The organ's ability to photosynthesize increases at the beginning of its development, but then begins to decline, sometimes before the organ is fully developed. This causes each plant to experience a phase where there is an increase in the rate of photosynthesis that is at the beginning of its development; as well as a decreasing phase of photosynthetic rate occurring at a certain age, which is different in each plant species.

The absolute growth rate of Gracilaria sp. at 30,45 and $60 \mathrm{~cm}$ depth respectively are $34,861 \mathrm{~g} ; 22,269 \mathrm{~g}$; and $16,389 \mathrm{~g}$; whereas the biomass at 30,45 and $60 \mathrm{~cm}$ depth were $8,803 \mathrm{~g} / \mathrm{m}^{2} ; 5,623 \mathrm{~g} / \mathrm{m}^{2}$ and $4,139 \mathrm{~g} / \mathrm{m}^{2}$ (Figure $3)$. Based on the analysis of variance (ANAVA), the depth of cultivation gives a significant effect both on the absolute growth $(p<0,05)$ and the biomass of Gracilaria sp. $(p<0.05)$. Duncan's multiple range tests show that $30 \mathrm{~cm}$ of depth provides the highest absolute growth and biomass of Gracilaria sp. than the other two depths.
The depth of cultivation will affect the intensity of light that entering the waters. Light intensity is a limiting factor for seaweeds growth. Seaweeds, like other plants, requires light (sunlight) to perform photosynthesis that is useful for its growth. According to Raikar et al. (2001), several main factors that have the most significant effect on the rate of seaweeds photosynthesis, ie light intensity, temperature and salinity. If the light intensity is less than optimal then the process of photosynthesis will be disrupted and resulting on slow growth. And conversely, if the light intensity is optimum then the process of photosynthesis will increase. Increased photosynthesis processes will increase the metabolic process that stimulates seaweeds to absorb more nutrients so the growth is better (Akmal et al., 2014).

\section{Water Quality}

The measurement of water quality parameters was done to determine the condition of waters for the growth of Gracilaria sp. During cultivation, the water quality at the cultivation site is still suitable for the growth of Gracilaria sp. (Table 1). 


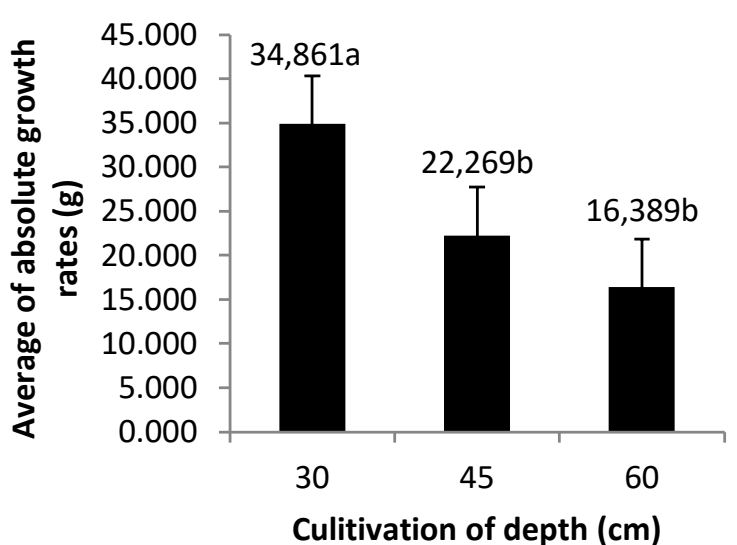

a) Average of absolute growth rates of Gracilaria $\mathrm{sp}$.

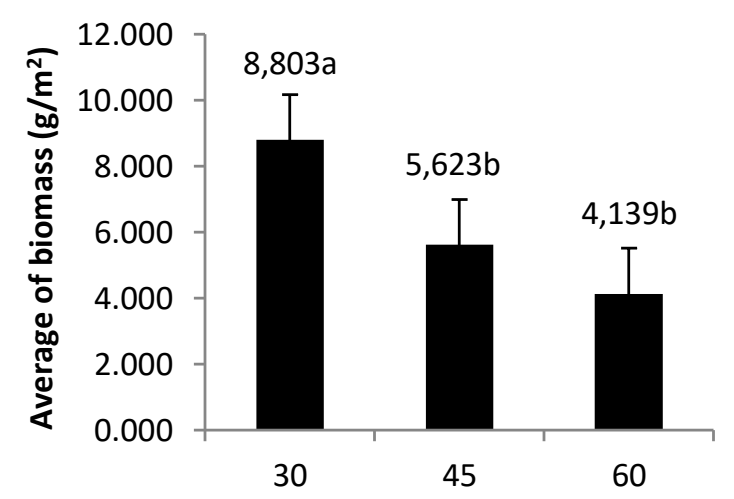

Culitivation of depth $(\mathrm{cm})$

${ }^{*}$ The number followed by different letters expresses the siginificant difference by DMRT $5 \%$

Figure 3. Comparison of absolute growth rates and biomass of Gracilaria sp. at various depths of cultivation.

Table 1. Results of water quality measurement of cultivation site

\begin{tabular}{llccl}
\hline No & \multicolumn{1}{c}{ Parameter } & Value & Optimum & \multicolumn{1}{c}{ Reference } \\
\hline 1 & Temperature $\left({ }^{\circ} \mathrm{C}\right)$ & 29 & $25-30$ & Ditjenkanbud (2005) \\
2 & Salinity $(\% \circ)$ & 27,333 & $15-30$ & WWF $(2014)$ \\
3 & Degree of acidity $(\mathrm{pH})$ & 8 & $6-9$ & WWF $(2014)$ \\
4 & Transparency $(\mathrm{cm})$ & 68,333 & $40-60$ & WWF (2014) \\
5 & Current velocity $(\mathrm{cm} / \mathrm{s})$ & 34,333 & $20-40$ & Anggadiredja et al. (2008) \\
\hline
\end{tabular}

\section{Temperature}

Temperature is one of the water quality parameters that play a role in the growth of seaweeds. According to Dawes (1981), water temperature can affect some physiological functions of seaweeds such as photosynthesis, respiration, metabolism, growth and reproduction. Based on the observations, the temperature at the study sites ranged from $25-30^{\circ} \mathrm{C}$ with an average of $29^{\circ} \mathrm{C}$. Overall, the temperature at the study sites is still suitable for seaweeds cultivation according to Ditjenkanbud (2005).

\section{Salinity}

Aquatic organisms, including seaweeds, have an osmoregulation system that allows it to survive a certain salinity range. Significant salinity changes can disrupt the osmoregulation mechanism and can lead to death. Salinity in the study sites ranged from 20 to $30 \%$, with an average salinity of 27,333 $\%$. Based on WWF (2014), salinity value during the study is still suitable for seaweeds cultivation. Gracilaria sp. is an organism that has a high tolerance range for salinity. According to Hoyle (1975), Gracilaria sp. can tolerate salinity with a range of $5-43 \%$.

\section{Degree of Acidity $(\mathrm{pH})$}

The $\mathrm{pH}$ values in the study sites ranged from 7.8 to 8.2 , with an average $\mathrm{pH}$ of 8 . According to the WWF (2014), the optimum pH for seaweeds cultivation range from 6-9. Based on the statement, the $\mathrm{pH}$ value at the study site is suitable for seaweeds cultivation. The $\mathrm{pH}$ values are influenced by several factors such as biological activities (photosynthesis and organism respiration), temperature and presence of ions in these waters (Pescod, 1973).

\section{Transparency}

The transparency of a waters is closely related to the penetration of sunlight into the waters. Seaweeds, like other plants, requires sunlight energy to perform photosynthesis, so transparency becomes one of the important factors determining the growth of seaweeds. Transparency at the study sites ranged from 65 to $70 \mathrm{~cm}$, with an average of $68.333 \mathrm{~cm}$. According to WWF (2014), the transparency for seaweeds cultivation ranges from 40 to 60 $\mathrm{cm}$. This means, at a depth of $60 \mathrm{~cm}$ sunlight can still penetrate into the waters. Based on WWF (2014), the transparency of the study 
site is still suitable for seaweeds cultivation because at a depth of $70 \mathrm{~cm}$, sunlight can still penetrate the waters. Marinho-Soriano et al. (2009) says that decreased penetration of sunlight into the water column can restrict the photosynthesis and seaweeds growth.

Current velocity

Strong current movements can keep the seaweeds clean from the sediment so that all parts of the seaweeds thallus can function optimally in the process of photosynthesis. Ryder et al. (2004) demosntrated that the lack of water movement significantly decreases growth rates of Gracilaria parvispora in ponds

\section{CONCLUSION}

Depth affects absolute growth and biomass of Gracilaria sp. The $30 \mathrm{~cm}$ depth provides the

\section{REFERENCES}

Abdan, A., Rahman, A., \& Ruslaini, R. (2013). Pengaruh jarak Tanam Terhadap Pertumbuhan dan Kandungan Karagenan Rumput Laut (Eucheuma spinosum) Menggunakan Metode Long Line. Jurnal Mina Laut Indonesia, 3(12), 113-123. Akmal, R. Syam, D.D. Trijuno, Rahmi, Darmawati. (2014). Content of Carrageenan, Chlorophyll a and Carotenoid of Kappaphycus alvarezii Cultivated in Different Seawater Depth Laikang Village, District of Mangarabombang, Takalar Regency. Journal of Applied Biotechnology, 2(1), 1 -9 .

Anggadiredja, T.J., Zatnika, A., Purwoto, H., \& Istini, S. (2008). Rumput Laut. Jakarta: Penebar Swadaya. Jakarta. 147 hal.

Aslan, M. (1998). Budidaya Rumput Laut. Kanisius. Yogyakarta. 97 hal.

Atmadja, W.S., Kadi, A., Safari, R. \& Sulistijo. (1996). Pengenalan Jenis-jenis Rumput Laut Indonesia. Puslitbang Oseanologi LIPI. Jakarta.

Dawes, C.J. (1981). Marine Botany. John Wiley Dawson University of South Florida. New York.

Ditjenkanbud. (2005). Profil Rumput Laut Indonesia. Direktorat Perikanan Budidaya, Departemen Kelautan dan Perikanan.Jakarta.

Domettila, C., Thankappan, S.S.B., Selvamony, S., \& Solomon, J. (2013). Diversity and distribution of seaweeds in the Mutton coastal waters, south-west coast of India. Biodiversity Journal, 4(1), 105-110.

Effendie MI. (1997). Biologi Perikanan. Yayasan Pustaka Nusatama. Yogyakarta. and lagoons in Hawaii. According to Atmadja et al. (1996), the faster the water movement, the more nutrients carried by water can be absorbed by the seaweeds through the diffusion process. But overcurrent currents can cause damage to cultivation construction and cause seaweeds thallus to be broken. The result of the measurement showed that the study site has a current velocity between 23 $51 \mathrm{~cm} / \mathrm{s}$, with an average current velocity is $34,333 \mathrm{~cm} / \mathrm{s}$. According to Anggadiredja et al. (2008), the current velocity suitable for seaweeds growth is $20-40 \mathrm{~cm} / \mathrm{s}$, so based on the statement, the current velocity in the study site is suitable for seaweeds cultivation.

highest absolute growth and biomass than the other two depths. Water quality measurements indicate that the study site is generally suitable for seaweeds growth.

Ganesan, M., S. Thiruppathi, K. Eswaran, C. R. K. Reddy, \& B. Jha. (2009). Cultivation of Gelidiella acerosa in the open sea on the southeastern coast of India. Marine Ecology Progress Series, 382, 49-57.

Hoyle, M.D. (1975). The literature pertinent to the red algal genus Gracilaria in Hawaii. Marine Agfonomi U.S. Sea Grant Program. Hawaii. $339 p$

Lakitan, B. (2011). Dasar-dasar Fisiologi Tumbuhan. Rajawali Pers. Jakarta. 206 hal.

Marinho-Soriano, E., Nunes, S.O., Carneiro, M.A.A., \& Pereira, D.C. (2009). Nutrients removal from aquaculture wastewater using the macroalgae Gracilaria birdiae. Biomass and Bioenergy, 33, 327-331.

Oliveira, V.P., Freire, F.A.M. \& Soriano, E.M. (2012). Influence of Depth on the Growth of the Seaweed Gracilaria birdiae (Rhodophyta) In a Shrimp Pond. Braz. J. Aquat. Sci. Technol, 16(1), 33-39.

Pescod, N. B. (1973). Investigation of Rational Effluent and Stream for Tropical Countries. Bangkok: AIT.

Raikar, S.V., Lima, M., \& Fujita, Y. (2001). Effect of temperatur, salinity and light intensity on the growth of Gracilaria spp. (Gracilariales, Rhodophyta) from Japan, Malaysia and India. Indian Journal of Marine Sciences, (30), 98-104.

Rebours C, Eliane M, Jose AZ, Leila H, Julio AV, Paul K, Gonzalo S, Raul U, Maria $H A$, Ingrid $B$, Grete $H$, Rolf R, \& Daniel R. (2014). Seaweeds: an opportunity for wealth and sustainable livelihood for coastal communities. J. Appl. Phycol, 26(5), 1939-1951.

Ryder, E., Nelson, S.G., Mckeon, C., Glenn, E.P., Fitzsimmons, K. \& Napoleon, S. 
(2004). Effect of water motion on the cultivation of the economis seaweed Gracilaria parvispora (Rhodophyta) on Molokai, Hawaii. Aquaculture, 238, 207 219.

Sahabuddin \& A. M. Tangko. (2008). Pengaruh Jarak Lokasi Budidaya dari Garis Pantai terhadap Pertumbuhan dan Kandungan Karaginan Rumput Laut Eucheuma cottoni. Prosiding Seminar Nasional Kelautan IV, 24 April 2008. Surabaya.

Siddique, M.A.M., Khan, M.S.K. and Bhuiyan, M.K.A. 2013. Nutritional composition and amino acid profile of a sub-tropical red seaweed Gelidium pusillum collected from St. Martin's Island, Bangladesh.
International Food Research Journal, 20(5), 2287-2292.

Wenno, P. A., Syamsuddin, R., Zainuddin, E. N., \& Ambo-Rappe, R. (2015). Cultivation of red seaweed Kappaphycus alvarezii (Doty) at different depths in South Sulawesi, Indonesia. Aquaculture, Aquarium, Conservation \& LegislationInternational Journal of the Bioflux Society (AACL Bioflux), 8(3), 468 - 473.

Widyanto, L.S. \& Susilo, H. (1977). Pencemaran oleh Logam Berat dan Hubungannya dengan Enceng Gondok. SEAMEO-BIOTROP.Bogor : Departemen PUTI.

WWF. (2014). Better Management Practices: Budidaya Rumput Laut Graciliria sp. di Tambak. Edisi 1. WWF Press. Jakarta. 